\author{
WALSh, Máté Gergely DR. \\ drmgwalsh@gmail.com
}

Student, Philosophy MA Program (University of Szeged, Hungary)

\title{
From Philosophy to Process Sociology
}

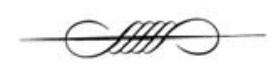

\begin{abstract}
This paper traces the early influences that shaped Norbert Elias's thought during his formative years in Breslau. Norbert Elias, a major figure of twentieth-century European sociology, built a unique research tradition known today as process sociology after rejecting philosophy at the beginning of his career and polemicized with the dominant social scientific schools of his time throughout his long life. This paper, examining Elias's less known early writings and particularly his doctoral thesis in philosophy disputed by his supervisor, Richard Hönigswald, argues that to better understand, value and utilize Norbert Elias's unique processual approach to sociology one must better understand the relationship between the neo-Kantian movement, a today neglected, but once a highly influential continental philosophical movement of the second half of the long nineteenth century, and the thinking of Elias's rebel generation in interwar Germany. This paper also intends to search for a common ground between the philosophical and the sociological traditions.
\end{abstract}

\section{KEYWORDS}

Norbert Elias, Hönigswald, neo-Kantianism, process sociology, philosophy, Weimar

DOI 10.14232/belv.2019.4.7 https://doi.org/10.14232/belv.2019.4.7

Cikkre való hivatkozás / How to cite this article: Walsh, Máté Gergely (2019): From Philosophy to Process Sociology. Belvedere Meridionale vol. 31. no. 4. 72-83. pp.

ISSN 1419-0222 (print) ISSN 2064-5929 (online, pdf)

(Creative Commons) Nevezd meg! - Így add tovább! 4.0 (CC BY-SA 4.0)

(Creative Commons) Attribution-ShareAlike 4.0 International (CC BY-SA 4.0)

www.belvedere-meridionale.hu 
Norbert Elias, who is best known in academic circles for his works related to historical sociology (Die höfische Gesellschaft 1969ํ․ Über den Prozeß der Zivilisation $1939^{2}$ ), was one of the most original figures of the twentieth-century sociological thought. The scope of his oeuvre extends far beyond what his popular image of a historian of manners and culture would suggest.

During his long career, Elias made a break with a number of common assumptions of the then-dominant schools of sociology, for example, that sociology is solely the study of advanced modern societies. Instead, he considered the study of long-term processes spanning through human history as one of the most important tasks of sociology. The goal for him was not merely a better understanding of modern societies but the better understanding of the human condition itself. ${ }^{3}$ As he pointed out quite early in his career, "if one wishes to understand man, if one wishes to understand oneself-every period of history is equally relevant to us ". ${ }^{4} \mathrm{He}$ relentlessly criticized the structural-functionalist and the Marxist sociological theory of the second half of the twentieth century together with phenomenology and systems theory, just like other disciplines such as history or psychology. He considered their individualistic, rationalistic, ideological, economistic and over-analytic tendencies, their overly abstract and static nature and the narrowness of their scope a hindrance to synthesis and understanding. ${ }^{5}$

He reserved his harshest words for philosophy, however. As Richard Kilminster put it "[Elias's critique] ....was based on a scientific conviction that the entire tradition of philosophy is historically defunct and cognitively deficient. For him, it would be scientifically and intellectually dishonest to argue otherwise. Philosophy is revealed as a superseded and potentially disorienting form of human orientation related to theology and magical mythical thought." ${ }^{\prime 6}$ His rejection of philosophy was a deeply held conviction that formed the core of his thought, the core of process sociology as it is known today, thus one cannot properly understand process sociology and the task of sociology according to Elias without understanding his critique of philosophy.

For this reason, the goal of this paper is to make an attempt towards the reconstruction of the influences that formed Norbert Elias's thought since his youth and evoked his rather radical stance, regarding some of his peers and philosophy in particular. It aims to adopt a non-dogmatic approach, however. The intent is not to justify or refute the considerations behind Elias's position but to reach a better understanding of his highly critical approach while remaining open to the arguments of the other side as well. To reconstruct the arguments that form the basis of his life's work, while not throwing out the proverbial baby - in this case two and a half millennia of the western philosophical tradition - with the bathwater, and if it's possible, to bridge the perceived chasm between philosophy and process sociology.

\footnotetext{
${ }^{1}$ English title: The Court Society.

${ }^{2}$ English title: On the Process of Civilization.

${ }^{3}$ Kilminster 2011. 91-92.

${ }^{4}$ Elias 2006a. 75.

${ }^{5}$ Kilminster 2011. 92.

${ }^{6}$ Kilminster 2011. 98.
} 
In order to achieve these goals, on the following pages I intend to revisit Norbert Elias's formative years in Breslau and the intellectual climate in academic philosophy in interwar Germany (the reasons behind the demise of neo-Kantianism in particular) with the help of some of Elias's little known early writings (his doctoral thesis in philosophy entitled Idee und Individuum: Eine kritische Untersuchung zum Begriff der Geschichte ${ }^{7}$ submitted in 1922 and its revised summary entitled Idee und Individuum: Ein Beitrag zur Philosophie der Geschichte ${ }^{8}$ published in 1924), his autobiographical essay published in 1984 (Notizen zum Lebenslauf 1984), a number of interviews he gave late in his life and a selection of secondary literature available in English on the philosophical and sociological trends of the era. I will only graze the subject of Elias's best-known works the aforementioned Die höfische Gesellschaft ${ }^{10}$, his doctoral thesis in sociology under the supervision of Karl Mannheim and the Über den Prozeß der Zivilisation ${ }^{11}$ because these texts were later heavily revised by Elias himself, therefore, they represent Elias's later thinking.

Although Elias wrote exclusively in German before the end of the Second World War, today's English-speaking readers are in the fortunate position that his entire oeuvre is available in authoritative English translation as well published by the University College Dublin Press. The translations were mostly approved by Elias himself. In the following, I am going to refer to the English editions of Elias's works.

\section{INTELLECTUAL INFLUENCES OF THE EARLY YEARS SPENT IN BRESLAU}

Elias was born in Breslau, a German city in the eastern part of the German Empire, what is today the Polish city of Wroctaw, on June 22, 1897, in a comfortably well-off German Jewish family. ${ }^{12}$ According to Elias's recollections, he wished to become a university professor from a very young age despite the numerous obstacles barring this career path from young men with a Jewish background in Wilhelmine Germany, thus, he oriented towards an intellectual career quite early in his life. ${ }^{13}$ He was first introduced to philosophy and to Kantian philosophy in particular, without which a proper philosophy education was unimaginable at that time, at the JohannesGymnasium in Breslau where he was taught by a distinguished staff (including Julius Stenzel who later became a professor of philosophy at the University of Kiel). ${ }^{14}$ Elias's interest in philosophy, which developed during these early years, proved to be lasting as he enrolled into the Faculty of Philosophy alongside the Faculty of Medicine at the Schlesische Friedrich-Wilhelms-Universität zu Breslau ${ }^{15}$ after his demobilisation from the Signal Corps in 1918 at the end of the First World War. During his philosophical studies in Breslau Elias also visited lectures in other German universities

\footnotetext{
${ }^{7}$ English title: Idea and individual: a critical investigation of the concept of history.

${ }^{8}$ English title: Idea and individual: a contribution to the philosophy of history.

${ }^{9}$ English title: Notes on a Lifetime.

${ }^{10}$ English title: The Court Society.

${ }^{11}$ English title: On the Process of Civilization.

${ }^{12}$ Mennell 1998. 4.

${ }^{13}$ Elias 2013a. 80.

${ }^{14}$ Elias 2013b. 6.

${ }^{15}$ Silesian Friedrich-Wilhelms University of Breslau.
} 
as it was customary among students at the time. In 1919 he attended the seminar of one of the leading neo-Kantian philosophers, Heinrich Rickert, in Heidelberg where he also got acquainted with and befriended the philosopher Karl Jaspers. Additionally, in 1920 Elias visited Freiburg where he attended the Goethe seminar of Edmund Husserl and probably got acquainted with Martin Heidegger who was Husserl's assistant between 1919 and $1923 .{ }^{16}$

The Schlesische Friedrich-Wilhelms-Universität zu Breslau, similarly to other German universities at the beginning of the twentieth century was dominated by neo-Kantian philosophy, a now largely neglected but then wildly influential continental philosophical movement. Neo-Kantianism started out at the end of the eighteenth century as a response to the decline of Kant's influence and to the rise of German idealism. More specifically it was a reaction to Karl Leonhard Reinhold's, Johann Gottlieb Fichte's and Friedrich Wilhelm Joseph Schelling's methods. The early neo-Kantians were aiming to rehabilitate Kantian philosophy after REINHOLD's Elementarphilosophie and FICHTE's Wissenschaftslehre had laid the groundwork for the rise of speculative idealism and gradually Kantian philosophy became obsolete in the eyes of the Romantic generation of young German philosophers. According to F. C. Beiser: "The founding fathers of the movement were Jakob Friedrich Fries (1773-1843), Johann Friedrich Herbart (1776-1841) and Friedrich Eduard Beneke (1798-1854). All defined themselves as Kantians, and all called for a return to the spirit of Kant's teachings. They anticipated, and laid down the foundation for, defining doctrines of later neoKantianism: the importance of the Kantian dualisms between essence and existence, understanding and sensibility; the limitation of all knowledge to experience; the leading role of a critical and analytical method in philosophy; and the need for philosophy to follow rather than lead the natural sciences." 17

Their success and eventual rise to dominance by the second half of the nineteenth century can be attributed to several factors shaping German society, intellectual life and philosophy in particular of the time. Two of these, German nationalism and German historicism were broad intellectual currents with influence extending far beyond the world of philosophical circles. On the one hand, the unified German state did not become a political reality until 1871 and Immanuel Kant, the first philosopher of international stature since Gottfried Wilhelm Leibniz was a source of great pride for Germans and played a major role in shaping the German cultural identity during the first half of the nineteenth century. German historicism, on the other hand, was an intellectual current that encouraged self-awareness, the reflection on, and recollection of one's origins, historical roots. Kant as a major figure of eighteenth-century continental European philosophy was obviously an important part of the origins and historical roots of modern German philosophy, therefore, it was an unavoidable task to trace his influence and the development of his thought for anyone who wished to understand what shaped modern German philosophy, how it came to be. ${ }^{18}$

Beyond these general intellectual currents that created interest towards Kant, the strictly philosophical rationale of neo-Kantianism, which helped the movement to become dominant, was also twofold. On the one hand, speculative idealism, one of the main competitors of neo-Kantianism, collapsed during the middle of the nineteenth-century after Georg Wilhelm Friedrich Hegel's death in 1831 and the end of the Prussian Reform Movement in 1840, and also partly due to the increasingly

\footnotetext{
${ }^{16}$ KILMINSTER 2006. xii-xiii.

${ }^{17}$ BEISER 2014. 3.

${ }^{18}$ BEISER 2014. 4-5.
} 
ferocious attacks on Hegelian philosophy beginning in the 1820s. Three of Hegel's major critics worth being highlighted in this regard were Friedrich Adolf TRENDELENBURG who in his Logische Untersuchungen (1840) launched a powerful attack against Hegel's dialectic, Rudolf Hermann LOTZE who in his Metaphysik (1841) exposed the weaknesses of Hegel's logic and Ludwig Andreas VON Feuerbach who with his Das Wesen des Christentums (1841) convinced non-Hegelians that Hegel's metaphysics is obsolete and they need to go beyond Hegel. This development was leaving neo-Kantianism as one of the main contenders with the chance of filling the vacuum left behind by the demise of speculative idealism in the German intellectual scene. ${ }^{19}$ On the other hand, during the 1860 s German intellectual circles were beginning to consider neo-Kantianism as one of the possible solutions to the major intellectual controversies of the time, namely, the so-called "identity crisis of philosophy" and the "materialism controversy".

The "materialism controversy" arose due to the increasing and all-conquering success of the empirical and particularly the natural sciences. The question was whether or not the success of the scientific enterprise is inevitably leading to the rejection of religion. It was an issue that was already present during the eighteenth-century and Kant's message, that a via media is possible between science and faith and one does not have to choose, still resonated strongly during the nineteenth century so much so that it helped the neo-Kantian movement to stall the materialist advance. The other major philosophical controversy of the time, the so-called "identity crisis of philosophy" also leads us back to the staggering success of the natural sciences and the already mentioned mid-nineteenth-century collapse of speculative idealism because these developments led many contemporaries to question the viability of philosophy itself. Their argument was that philosophy became obsolete and today it has nothing more to offer than, as Beiser puts it, "metaphysical hocus-pocus". Amidst these difficult times, the promise of the neo-Kantian movement was that through the examination of the methods, standards and presuppositions of the empirical sciences, philosophy can redefine itself as epistemology and exist independently from science but also benefit from its success. ${ }^{20}$ Ironically, more than a hundred years later this seemingly successfully and strategically handled controversy that propelled neo-Kantianism into a dominant position within the German academia resurfaced and Elias questioned the status of philosophy due to its "emptiness" once again.

In reality, by the time Elias started his philosophical studies, neo-Kantianism was already in decline and the major cataclysmic events at the beginning of the twentieth century only hastened its fall until all remaining neo-Kantian philosophical circles were dissolved following Hitler's rise to power in 1933. The 1920s was a period of turbulent transition and generational conflict in Germany and also in Europe as a whole. It was a period of severe economic problems, social unrest and political strife following the devastation of the First World War, which provided very different social conditions for intellectual development and political socialization for Elias's generation than what had been experienced by earlier generations, including their parents' generation. ${ }^{21}$ For Elias and his generation, it brought the feeling that the old world is gone forever and generated resentment towards the establishment of the pre-war period. In the case of philosophy, this meant

\footnotetext{
${ }^{19}$ BeISER 2014. 5-6.

${ }^{20}$ BeISER 2014. 6.

${ }^{21}$ KILMinster 2007. 10.
} 
a resentment towards neo-Kantian philosophers who were still dominating academic philosophy. The philosophers, sociologists, psychoanalysts of Elias's generation, including major intellectual figures like Karl Mannheim, Hannah Arendt, Theodor Adorno and Sigmund Henry Foulkes were addressing remarkably varied practical issues and theoretical dilemmas connected to all areas of economic, social, political and personal life while they were searching for new ways and polemicizing with the overlapping earlier generation of major thinkers as Karl Jaspers, Martin Heidegger, Edmund Husserl, Max and Alfred Weber, Georg Simmel, Thorstein Veblen and others. ${ }^{22}$ Looking strictly at the philosophical developments of the period: “... the 'new beginnings' of the time included, as well as existentialism and fundamental ontology, the logical positivism of the Vienna Circle and the philosophy of the early Wittgenstein. All of these in their different ways sought to make visible 'the hidden and stifling presuppositions' of Western thought as a way of trying to understand how traditional forms of thinking that seemed to have served people very well, no longer did so. A philosophical 'renewal of the West'was regarded as fundamental because 'the ancient Christianreligious foundations of life had been badly shaken'. '"23 Elias's generation found neo-Kantian philosophy to be way too idealistic, individualistic philosophy of consciousness which got lost in futile epistemological discussions and devalued the real problems of the real world. Refusing this, they searched for a philosophy that can find practical answers to real-life problems and if such philosophy cannot be found, they were willing to abandon the philosophical enterprise altogether and turning towards the seemingly greener pastures of other younger disciplines such as sociology. ${ }^{24}$

It's important to note this above described Zeitgeist because as it is evident from Elias's dispute with Richard HöNIGSWALD (his Doktorvater ${ }^{25}$ ) or more precisely from how he presented the dispute in retrospective, he was a child of his time more than he liked to admit it. Elias stated numerous times during his career that this dispute was his point of departure on his road towards the rejection of neo-Kantianism and philosophy as a whole. The dispute according to Elias's recollections revolved around the neo-Kantian doctrines of a priori and timeless validity (Geltung) ${ }^{26}$ A doctrine that asserted certain categories of thought, such as Newtonian, space, time, causality and some fundamental moral principles are not derived from experience, instead, they are inherent, eternal and universal to the human mind. ${ }^{27}$ Elias thought this assertion to be untenable. As Richard Kilminster recalls Elias's position on the matter: "Elias complained many times that the doctrine of the a priori was defeatist because it shackles human thinking forever to fixed categories and flies in the face of evidence of the advancing syntheses historically developed in the sciences in the light of new observations. In addition, that commitment to the principle of Geltung was inherently contradictory in a timebound world. ${ }^{28}$ Studies published since the $1990 \mathrm{~s},{ }^{29}$ however, showed that Elias somewhat

\footnotetext{
${ }^{22}$ KILMINSTER 2007. 11.

${ }^{23}$ KiLMinSter 2007. 12.

${ }^{24}$ KiLMinSTER 2011. 93-94.

${ }^{25}$ Richard Hönigswald (1875-1947) a Hungarian born major figure of the late neo-Kantian movement was the professor of philosophy at the Philosophy Faculty of the Schlesische Friedrich-Wilhelms-Universität zu Breslau during Elias's years of studying there and he was the supervisor, called Doktorvater in German, of Norber Elias's doctoral thesis in philosophy.

${ }^{26}$ ELIAS 2013b. 13.

${ }^{27}$ MenNell 1998. 8.

${ }^{28}$ Kilminster 2007. 9.

${ }^{29}$ Kilminster 2007. 9.
} 
exaggerated the rigidness of Richard Hönigswald's and the neo-Kantian's position in general. The neo-Kantians were actually quite aware of the fact that these categories and scientific concepts had social origins. None of them, including Hönigswald, ever claimed that the above-mentioned Kantian categories were timeless, eternal and unlearned as Elias alleged and they were perfectly ready to accept the contrary. Furthermore, both parties found the attainment of valid knowledge important, although, Elias went somewhat further and he was interested also in the issue of in what process concepts or knowledge acquire their validity. ${ }^{30}$ In other words, in retrospect, it appears validity wasn't actually the main reason why Elias's path and the path of the neo-Kantians got separated, rather the personal conflict between Elias and Hönigswald which made it impossible for him to continue his university career in philosophy. Elias recalls in his autobiographical essay that after his dispute with Hönigswald, although, he eventually accepted Elias's doctoral dissertation, it seemed pointless to ask for further support. ${ }^{31}$

Contrary to his already intense interest in philosophy, his enrolment in the Faculty of Medicine was a choice made partly at his father's request. Although, he eventually abandoned his medical studies by the end of his pre-clinical semesters, his medical studies also had a profound influence on his intellectual development. Both in his autobiographical essay and his autobiographical interview, Elias recalls his memories of his anatomy lectures and his experiences in the dissecting room as sources of inspiration for questioning the neo-Kantian doctrines and eventually for the rejection of philosophy altogether, and also for developing the opposing concepts of the homo clausus and the homo aperti. ${ }^{32}$ His knowledge of the human anatomy and his practical experience acquired through performing autopsies helped him realize that human beings are by nature social creatures attuned to living together with their own kind, as indicated for example by the unusually complex musculature of the human face compared to other members of the animal kingdom. These experiences also made him question if there is anything in the human brain and nervous system that supports the neo-Kantian image of humans. It seemed to him that nothing corresponds with the supposed division of the "external" and the "internal world of the mind", a notion that runs through the history of western philosophy since Plato and which brought about the preoccupation with the problem of how the single individual adult mind looking out from inside can acquire knowledge about the external world. ${ }^{33}$ Stephen Mennell eloquently summarizes this problem of the homo clausus in his monography about Elias's life and work: "It is the conception of the person (in the singular) as the 'subject' of knowledge; a single thinking mind inside a sealed container, from which each one looks out and struggles to fish for knowledge of the 'objects' outside in the 'external world'. Among those 'objects' are other minds, equally locked inside their own sealed containers, and one of the most difficult problems epistemologists (and sociologists influenced by them) pose for themselves is the question of how one thinking 'subject'inside its own container can ever know anything of what is being thought and what is known by those 'objects' - those of other 'subjects'thinking away inside their own containers in turn. ${ }^{34}$

\footnotetext{
${ }^{30}$ KILMINSTER 2007. 9.

${ }^{31}$ ELIAS 2013b. 13-14.

${ }^{32}$ Elias 2013b. 8-11, 2013. 96.

${ }^{33}$ MenNell 1998. 7.

${ }^{34}$ MenNell 1998. 189.
} 
In Elias's mind, the homo clausus is a form of process reduction in western thinking, spread by philosophy, which creates the illusion that one can discover eternal, unchanging conditions. In reality, however, it produces only highly arbitrary law-like generalizations reflecting only the given phase of the development of human knowledge. It's one of the main goals of sociology to leave behind the homo clausus mindset and to adopt a new processual way of thinking which he in his much later works called the homo aperti. As examples of the homo clausus mindset from the history of philosophy one can mention Plato's allegory of the cave in the Republic, the proposition of cogito ergo sum in Descartes's Discourse on the Method, the concept of the windowless monads in Leibniz's The Monadology and of course Kant's philosophy which was at the root of the conflict between him and Richard Hönigswald. A conflict that I will try to reconstruct in detail in the second part of the paper.

\section{THE BREAK WITH HöNIGSWALd AND NEO-KANTIANISM}

Norbert Elias has submitted his doctoral thesis entitled Idee und Individuum: Eine kritische Untersuchung zum Begriff der Geschichte in 1922 which got accepted with much delay only in 1924 due to his personal financial difficulties caused by the post-war hyperinflation in Germany between 1920 and late 1923 (he had to accept a temporary job outside academia to support himself and his parents) and his conflict with his supervisor. Richard Hönigswald finally accepted an abbreviated version of his doctoral thesis from which the most disputed parts were removed and a new summary was published entitled Idee und Individuum: Ein Beitrag zur Philosophie der Geschichte, which due to the concessions made to Hönigswald, contradicts the dissertation itself on a number of points. Although Elias himself has never looked for it again, 54 pages of the originally 57 pages long typescript of the dissertation survived the tumultuous first half of the twentieth century, during which much of the otherwise impressive collection of the library of the Schlesische Friedrich-Wilhelms-Universität zu Breslau was destroyed, and it was discovered fifty-six years later in the archives of the Uniwersytet Wroctawski. On the cover of the original typescript, it is indicated in Elias's handwriting that the pages 55-57 are missing. In all probability, these were the pages that had to be removed to meet Hönigswald's demands. The dissertation is written according to the academic customs of the era without direct quotations or citations from other authors in the form of an "extended rigorous philosophical argument". ${ }^{35}$ It is a highly involved philosophical text, heavy with neo-Kantian philosophical jargon. Fortunately, Elias's reflections on the rediscovered dissertation are available from the 1980 s to help the interpretation. ${ }^{36}$

The dissertation is concerned with the same problems that interested Elias during most of his life and especially in his two most famous works, Die höfische Gesellschaft which has its origins in his Habilitation thesis in sociology entitled Der höfische Mensch: Ein Beitrag zur Soziologie des Hofes, höfischen Gesellschaft und des absoluten Königtums ${ }^{37}$ written under Karl Mannheim's

\footnotetext{
${ }^{35}$ KILMINSTER 2006. xii-xiv.

${ }^{36}$ ELIAS 2013c.

${ }^{37}$ The title in English: The court person: a contribution to the sociology of the court, court society and the absolute monarchy.
} 
supervision and submitted in 1933 to the Johann Wolfgang Goethe-Universität Frankfurt am Main ${ }^{38}$ and the Über den Prozeß der Zivilisation his main work written in emigration in England, namely the structure of unplanned social processes and the relation between physical and social time from a philosophical point of view. In both of his main works, Elias tries to retrace the long-term historical processes behind the emergence of modern European states. Elias writes the following in his reflections: "As early as my dissertation, therefore, I had been puzzling over what I later called 'as sequential order', the specific order within which a later event arises from a specific sequence of earlier events. At that time I was wondering about questions that are still of the utmost interest to me today - for example, the question of how a later form of a state emerges from an earlier one which in turn emerges from a yet earlier, a later form of knowledge from earlier ones and, more generally, how later forms of human social life emerge from earlier ones. Already present as well as the problem of the relation of physical to social time... ",39

In his philosophy doctoral dissertation, however, contrary to his later works in which his outlook is distinctly historical-sociological, Elias tries to conceptualise the stages of social development philosophically as a sequence of mental structures (which makes the original topic of his Habilitation thesis quite understandable) starting his argument with the problem of how a historian sifts through the abundance of material produced by humanity and how he selects and separates the facts that merit his work from those that he is leaving aside as something without significance. He claims that the criteria for selection cannot come from arbitrary pre-posited precepts but from the structure of the material itself and writes that: "The object of historical investigation is not a structureless mass of events which it would be futile to attempt to grasp in retrospect, but a sequence of facts which are organised and linked together by a framework of a characteristic order. " ${ }^{40}$ He states that even if the historian singles out a single historical fact, other facts that are close to it in space and time will emerge as other possibly relevant facts. Eventually, this will place the entire epoch in which the original historical fact belongs in a new light and vice versa. Meaning, the studying of a historical epoch will bring the historian's attention to individual facts as well. Elias calls this structure of the individual historical facts the 'idea' and sets out to examine the specific relationship between the individual facts and the underlying structure of the idea, or as he explains: "Now, to make this selection it is important, above all, that the historian should know what it is to be understood by an 'idea'. This term, which has been bandied about too much in the course of history, has become so misunderstood that even its cautious use in the preceding discussion can signify nothing more than that there is, underlying history, a peculiar formation which is commonly called 'idea'. This idea and its relationship to the individual historical fact, to the 'individual' in the widest sense of the term, harbour a particular problem. From the solution to this problem historians may expect to gain clarity on the principle of historical selection and on the legitimacy of their

\footnotetext{
${ }^{38}$ One could also mention the original topic for his Habilitation thesis on which he embarked upon when, after he earned his doctorate in philosophy in Breslau, he moved to Heidelberg to pursue further studies in sociology under the supervision of Alfred Weber, that is the genesis of the modern natural sciences with a special focus on the Italian Renaissance. (MENNELl 2006. xi.)

${ }^{39}$ ELIAS 2013c. 301-302.

${ }^{40}$ Elias 2006b. 23.
} 
own procedure, while philosophers may hope to gain insight into the structure of history and proof of the claim to truth which historical judgment require."

In his reflections he considers this above described inquiry as one of his early attempts to point out that a historical fact is a function of its position within the historical process, meaning that human experiences are not only events that came before and reasons for what comes after but at least in part they are also determining how the past is interpreted from the present, which facts we pick as reasons for interpreting present events. He cites the example of the relationship between the so-called modern age and the 'Middle Ages'. The 'Middle Ages' in our modern understanding is not simply an epoch that was before the modern age. Its image is also shaped by the fact that the modern age came after it and to understand it we need to look at what the 'Middle Ages' was like before the modern age came about. Elias, in order to explicate this in his dissertation, uses a Hegelian process model that was known to him at the time. ${ }^{42}$

The conflict with Hönigswald arose from the mode of how Elias attempted to surpass some of the fundamental doctrines of neo-Kantian philosophy and the comparison between the dissertation and the accompanying summary submitted two years after the submission of the dissertation is our best clue to reconstruct the nature of the conflict as Elias systematically backtracks on every major issue unacceptable to Hönigswald, thus creating contradictions between the dissertation and its summary. The most glaring examples are the three invariants mentioned in the summary as Elias explicitly contradicts statements made in the dissertation by endorsing them. The first of these invariants is time or the natural event which gives the historical fact its determinateness, the second is someone's experience or more precisely the relationship between the 'I' and the natural event, which makes the natural event historical and the third is validity, the conformity of meaningstructures to norms which belong to a system of history. ${ }^{43}$ Elias also notes in his reflections the concessions made in his dissertation in order to finally receive Hönigswald's approval: "It is also clear in this text how I tried to get around my research supervisor's categorical rejections of one of my central arguments with a compromise formula. In the last paragraph I pointed out that, as I had presented the matter, each single idea emerges as consequence from reasons, and 'can thus even be subject to the laws of the dialectical process'. But I added that 'the idea of validity as a principle of the dialectical process is not subject to its movement'. In this last sentence I made my bow to the philosophical fetish of the concept of validity..."

\section{Conclusion}

On the previous pages I made an attempt to trace the intellectual influences of Norbert Elias's formative years which he spent mostly in Breslau from the end of the long nineteenth century until the mid-1920s of interwar Germany and I tried to reconstruct Elias's dispute with Richard Hönigswald, the supervisor of his doctoral dissertation in philosophy which set Elias on the path of rejecting philosophy as a magical mythical mode of thinking and a thing of the past.

\footnotetext{
${ }^{41}$ Elias 2006b. 24-25.

${ }^{42}$ Elias 2013c. 302.

${ }^{43}$ Elias 2006c. 55-56.

${ }^{44}$ Elias 2013c. 302-303.
} 
In connection with the first issue, we have seen that the neo-Kantian movement, which started out as a counterreaction to the declining influence of Immanuel Kant during his final years at the end of the eighteenth-century and which rose to dominance at the middle of the nineteenth-century after the collapse of German speculative idealism, was already in decline when Elias began his studies at the Philosophy Faculty of the Schlesische Friedrich-Wilhelms-Universität zu Breslau. We have also seen that during the 1920s a rebel generation of thinkers emerged in interwar Germany, Elias among them, who were deeply resentful towards the political and intellectual establishment which in the case of philosophy meant a resentment of the authority of the older neo-Kantian philosophers in German universities. Social strife and social change created an incredibly lively intellectual milieu in which the younger generation of philosophers, sociologists and psychoanalysts were actively searching for practical solutions for real-life problems in all areas of life while polemicizing with the previous generations and they were perfectly ready to stray from the known paths. Thus, although Elias's experiences as a medical student certainly served as catalysts for his rejection of philosophy and the formulation of his unique processual approach towards sociology, we cannot justifiably claim that Elias was a solitary genius alone with his criticism towards and rejection of philosophy. In fact, in many ways, he followed the example set by his peers. As Richard Kilminster writes: "In common with many other younger philosophers at this time, Elias was rebelling against the neo-Kantians' idealism, individualism and neglect of concrete realities. The institutional prominence and mandarin authority of this philosophical establishment were substantial. Elias was part of a wider movement of intellectual opposition in the 1920s (which included the existentialists and fundamental ontologists such as Heidegger) to the rationalism of Kantianism. In that sense, Elias was riding a critical wave, not of his common making. But the particular character of Elias's approach to a critique of Kant in the dissertation became a serious problem for his relationship with Hönigswald. " 45

In connection with the second issue, I have attempted to reconstruct Elias's argument set forth in his philosophy dissertation. We have seen that problems that interested Elias throughout his long life were already present in his dissertation, namely, the issue of the structure of unplanned social processes and the issue of the relationship between physical and social time. Thus, his dissertation is an important document if one wishes to better understand Elias's later thinking and the development of his ideas. Regarding his dispute with Hönigswald, very little is certain as the conclusion of his dissertation is missing. What seems to be certain, however, is that he did assume a position that was difficult to defend by choosing to criticise the fundamental doctrines of neo-Kantianism in his dissertation. At this point in my inquiry, however, I believe that his rejection of philosophy came more of as a necessity due to his dispute with Hönigswald than as an unavoidable conclusion of his critique of neo-Kantianism. In this paper, I did not make an attempt to reconstruct how Elias's early critique of philosophy developed in his later works but it seems to me that it is necessary to continue the inquiry in order to make a final judgment about the relations between philosophy and process sociology.

\footnotetext{
${ }^{45}$ KILMINSTER 2006. xiii-Xiv.
} 


\section{REFERENCES}

BeISER, Frederick C. (2014): The Genesis of Neo-Kantianism, 1796-1880. Oxford, Oxford University Press.

Crowell, Steven Galt (1999): Neo-Kantianism. in Simon Critchley and William R. Schroeder (eds.): A Companion to Continental Philosophy. Oxford, Blackwell. 185-197.

Elias, Norbert (2006a): Contribution to the debate on Richard Thurnwald, 'On primitive art'. In Elias, NorberT: Early Writings. Dublin, University College Dublin Press. 71-75.

Elias, Norbert (2006c): Idea and individual: a contribution to the philosophy of history. In Elias, NorberT: Early Writings. Dublin, University College Dublin Press. 56-57.

Elias, NORBERT (2006b): Idea and individual: a critical investigation of the concept of history. In Elias, Norbert: Early Writings. Dublin, University College Dublin Press. 23-53.

ELIAS, NORBERT (2013a): Norbert Elias's story of his life (1984). Interview with Arend-Jan Heerma van Voos and Bram van Stolk. In ElIAS, NORBERT: Interviews and Autobiographical Reflections. Dublin, University College Dublin Press. 71-140.

Elias, Norbert (2013b): Notes on a Lifetime (1984). In Elias, Norbert: Interviews and Autobiographical Reflections. Dublin, University College Dublin Press. 4-67.

ELIAS, NorberT (2013c): On re-reading my doctoral dissertation. In ElIAS, NORBERT: Interviews and Autobiographical Reflections. Dublin, University College Dublin Press. 301-303.

Kilminster, Richard (2006): Note on the Text. In Elias, Norbert: Early Writings. Dublin, University College Dublin Press. xi-xx.

KILMINSTER, Richard (2007): Norbert Elias: Post-philosophical sociology. Routledge, New York. KILMINSTER, RICHARD (2011): Norbert Elias's post-philosophical sociology: from 'critique' to relative detachment. The Sociological Review volume 59. issue 1. 91-116.

Mennell, StePhen (1998): Norbert Elias: An Introduction. Dublin, University College Dublin Press.

Mennell, Stephen (2006) Note on the Text. In Elias, Norbert: The Court Society. Dublin, University College Dublin Press. xi-xv. 